\title{
ANALISIS PENGARUH LIKUIDITAS, LEVERAGE, AKTIVITAS, DAN \\ PROFITABILITAS TERHADAP FINANCIAL DISTRESS PADA PERUSAHAAN TERBUKA SEKTOR INFRASTRUKTUR, UTILITAS, DAN TRANSPORTASI PERIODE 2011-2015
}

\author{
Rizky Kartika ${ }^{1}$ \\ Hasanudin ${ }^{2}$ \\ ${ }^{1,2}$ Fakultas Ekonomi dan Bisnis Universitas Nasional
}

Email: $\underline{\text { iamrizky@gmail.com }}{ }^{1}, \underline{\text { hasanudin2005@yahoo.com }}^{2}$

\begin{abstract}
ABSTRAK
Penelitian ini bertujuan untuk menganalisis pengaruh likuiditas, leverage, aktivitas dan profitabilitas terhadap financial distress pada perusahaan terbuka di sektor infrastruktur, utilitas, dan transportasi. Dengan menggunakan metode purposive sampling, diperoleh 32 perusahaan sebagai sampel penelitian dengan tahun 2011-2015 digunakan sebagai periode penelitian. Metode analisis yang digunakan adalah metode analisis inferensial dengan menggunakan regresi logistik. Hasil penelitian menunjukkan bahwa: (1) likuiditas (CR) berpengaruh negatif dan signifikan terhadap financial distress; (2) leverage (DAR) berpengaruh positif dan signifikan terhadap financial distress; (3) aktivitas (TATO) berpengaruh negatif dan signifikan terhadap financial distress; dan (4) profitabilitas (ROA) berpengaruh negatif dan signifikan terhadap financial distress.
\end{abstract}

Kata kunci: Financial distress, likuiditas, leverage, aktivitas, profitabilitas

\section{ABSTRACT}

This research aims to analyze the influence of liquidity, leverage, activity and profitability on financial distress in public companies in the infrastructure, utility and transportation sectors. By using purposive sampling method, obtained 32 companies as the samples of the research with 2011-2015 used as the research period. The analysis method used is inferensial analysis method by logistic regression. The results of the research show that: (1) liquidity (CR) has negative and significant effect on financial distress; (2) leverage (DAR) has positive and significant effect on financial distress; (3) activity (TATO) has negative and significant effect on financial distress; and (4) profitability (ROA) has negative and significant effect on financial distress.

Keywords: Financial distress, liquidity, leverage, activity, profitability

\section{PENDAHULUAN}

Persaingan yang semakin ketat dan kondisi perekonomian domestik yang tidak stabil akibat pengaruh perekonomian global dinilai memberikan dampak yang cukup besar bagi kinerja keuangan perusahaan di Indonesia. Salah satu faktor perekonomian makro yang memberikan dampak yang cukup signifikan terhadap kinerja keuangan perusahaan adalah inflasi dan depresiasi rupiah yang menyebabkan naiknya biaya produksi serta turunnya daya beli masyarakat dan laba perusahaan. Hal tersebut menyebabkan ancaman financial distress menjadi semakin nyata. 
Berikut ini merupakan data laba bersih beberapa perusahaan di sektor infrastruktur, utilitas dan transportasi pada periode 2011-2015.

Tabel 1. Laba (Rugi) Bersih per Saham (EPS) Sektor IUT Periode 2011-2015

\begin{tabular}{|c|l|r|r|r|r|r|}
\hline \multirow{2}{*}{ No } & \multicolumn{2}{|c|}{ Perusahaan } & \multicolumn{4}{c|}{ Laba dan Rugi Bersih per Saham (Rp) } \\
\cline { 3 - 7 } & & $\mathbf{2 0 1 1}$ & $\mathbf{2 0 1 2}$ & $\mathbf{2 0 1 3}$ & \multicolumn{1}{c|}{$\mathbf{2 0 1 4}$} & $\mathbf{2 0 1 5}$ \\
\hline 1 & PT Leyand International Tbk & 0,74 & 2,54 & $-0,67$ & $-10,95$ & $-12,53$ \\
\hline 2 & PT Indosat Tbk & 178,26 & 69,03 & $-513,11$ & $-369,60$ & $-241,08$ \\
\hline 3 & PT XL Axiata Tbk & 332,00 & 324,00 & 121,00 & $-95,00$ & $-3,00$ \\
\hline 4 & PT Arpeni Pratama Ocean Line Tbk & $-690,00$ & $-88,00$ & $-103,00$ & 2,00 & $-87,00$ \\
\hline 5 & PT Zebra Nusantara Tbk & $-14,24$ & $-13,27$ & $-15,82$ & $-10,45$ & $-9,75$ \\
\hline 6 & PT Truba Alam Manunggal Engineering Tbk & $-29,00$ & $-52,00$ & $-35,00$ & $-4,00$ & $-38,00$ \\
\hline
\end{tabular}

(Sumber: BEI, 2016)

Berdasarkan tabel di atas, beberapa perusahaan di sektor insfrastruktur, utilitas dan transportasi terindikasi mengalami financial distress karena membukukan EPS yang bernilai negatif selama beberapa tahun terakhir. Penggunaan EPS negatif sebagai indikator financial distress itu sendiri mengacu pada penelitian terdahulu yang dilakukan oleh Widhiari dan Merkusiwati (2015) dan Sastriana dan Fuad (2013).

Indikasi financial distress yang dialami oleh perusahaan-perusahaan di sektor infrastruktur, utilitas dan transportasi perlu ditanggapi secara serius agar perusahaanperusahaan tersebut tidak mengalami kebangkrutan. Sementara itu, perusahaan-perusahaan lainnya yang tidak terindikasi mengalami financial distress perlu mempertahankan dan meningkatkan kinerjanya agar senantiasa terhindar dari gejala financial distress di kemudian hari. Dalam kaitannya dengan hal-hal tersebut, perlu dilakukan penelitian untuk menganalisis variabel-variabel yang dapat secara signifikan mempengaruhi financial distress dalam rangka mencari alat yang dapat digunakan untuk mencegah financial distress dan kebangkrutan.

Hasil penelitian yang dilakukan oleh Widhiari dan Merkusiwati (2015) serta Hidayat dan Meiranto (2014) menemukan bahwa salah satu variabel yang dapat mempengaruhi financial distress secara signifikan adalah variabel likuiditas yang diproksikan dengan current ratio. Dalam penelitian tersebut, likuiditas terbukti berpengaruh negatif dan signifikan terhadap financial distress, sehingga semakin tinggi kemampuan perusahaan dalam memenuhi kewajiban jangka pendeknya, maka semakin rendah kemungkinan terjadinya financial distress pada perusahaan tersebut.

Variabel lain yang dapat berpengaruh signifikan terhadap financial distress adalah leverage. Hasil penelitian yang dilakukan oleh Yustika, dkk. (2015) serta Lisiantara dan Febrina (2018) menemukan bahwa leverage yang diproksikan dengan debt ratio terbukti 
memiliki pengaruh yang positif dan signifikan terhadap financial distress. Hal tersebut menunjukkan bahwa semakin tinggi proporsi penggunaan utang dalam pembiayaan aset perusahaan, maka semakin rendah pula kemungkinan terjadinya financial distress pada perusahaan tersebut.

Financial distress juga dapat dipengaruhi oleh aktivitas perusahaan. Hasil penelitian yang dilakukan oleh Noviandri (2014) serta Widhiari dan Merkusiwati (2015) menemukan bahwa aktivitas perusahaan yang diproksikan dengan total asset turnover ratio terbukti memiliki pengaruh yang negatif dan signifikan terhadap financial distress. Hal tersebut menunjukkan bahwa semakin tinggi kemampuan perusahaan dalam mengelola asetnya secara efektif, maka semakin rendah kemungkinan terjadinya financial distress pada perusahaan tersebut.

Profitabilitas juga dapat berpengaruh signifikan terhadap financial distress. Hal tersebut dibuktikan oleh hasil penelitian yang dilakukan oleh Yustika, dkk. (2015) serta Nukmaningtyas dan Worokinasih (2018) yang menemukan bahwa profitabilitas yang diproksikan dengan return on asset terbukti memiliki pengaruh yang negatif dan signifikan terhadap financial distress. Hal ini menunjukkan bahwa semakin tinggi kemampuan perusahaan dalam menghasilkan laba, maka semakin rendah kemungkinan terjadinya financial distress pada perusahaan tersebut.

Berdasarkan latar belakang tersebut, perlu dilakukan penelitian untuk menganalisis signifikansi pengaruh likuiditas, leverage, aktivitas dan profitabilitas terhadap financial distress pada perusahaan terbuka di sektor infrastruktur, utilitas dan transportasi dalam upaya menemukan variabel yang dapat digunakan untuk mencegah dan mengatasi financial distress serta mencegah terjadinya kebangkrutan.

\section{TINJAUAN PUSTAKA}

\section{Financial Distress}

Menurut Sjahrial (2007:453), financial distress merupakan suatu kondisi yang terjadi ketika aliran kas operasi suatu perusahaan tidak dapat memenuhi berbagai kewajibannya, sehingga perusahaan tersebut dituntut untuk memperbaikinya. Sementara itu, Platt dan Platt (2002) mengartikan financial distress sebagai penurunan kondisi finansial perusahaan sebelum kebangkrutan ataupun likuidasi. Menurut Almilia (2006), financial distress dapat ditandai oleh laba bersih negatif selama beberapa tahun. 
Financial distress itu sendiri memiliki dampak yang cukup fatal, mulai dari kegagalan bisnis (business failure), insolvency ataupun kebangkrutan (Gitman, 2002). Menurut Sudana (2011:250), financial distress dapat diatasi dengan cara-cara berikut.

1. Penyelesaian Sukarela

Penyelesaian ini dilakukan dengan jalan membuat kesepakatan di antara kreditur dan debitur. Penyelesaian ini memiliki beberapa alternatif, yaitu sebagai berikut.

\section{a. Extensions}

Dalam alternatif ini, kreditur dan debitur membuat kesepakatan untuk memperpanjang waktu jatuh tempo utang.

b. Composition

Dalam alternatif ini, kreditur bersedia untuk menerima pembayaran sebagian utang dan merelakan sebagiannya menjadi tidak terbayarkan melalui persetujuan yang legal.

\section{c. Liquidation by Voluntary Aggreement}

Dalam alternatif ini, kreditur membuat kesepakatan untuk meminta dilakukannya likuidasi dengan kesepakatan stockholders.

2. Penyelesaian Melalui Pengadilan

Penyelesaian ini merupakan penyelesaian hukum dengan cara likuidasi yang dilakukan jika kreditur dan debitur tidak memperoleh kesepakatan melalui jalur sukarela dan perusahaan tidak mampu memperbaiki kondisi finansialnya.

\section{Likuiditas}

Menurut Martono dan Harjito (2010:55), likuiditas merupakan indikator kemampuan perusahaan untuk melunasi kewajiban finansialnya pada saat jatuh tempo dengan menggunakan aset lancar yang dimilikinya. Sementara itu, Mardiyanto (2009:54) mendefinisikan rasio likuiditas sebagai ukuran kemampuan perusahaan untuk melunasi utang jangka pendeknya tepat waktu dan sebagian utang jangka panjangnya yang jatuh tempo di tahun yang sama.

Salah satu rasio yang dapat digunakan untuk mengukur likuiditas adalah rasio lancar (current ratio), yaitu rasio yang oleh Kasmir (2014:134) didefinisikan sebagai ukuran kemampuan perusahaan dalam memenuhi utang jangka pendeknya ataupun utangnya yang segera jatuh tempo. Menurut Weygandt, et al. (2013:696), rasio ini merupakan perbandingan antara current assets dan current liabilities suatu perusahaan. 


\section{Leverage}

Menurut Kasmir (2014:113) rasio leverage adalah rasio yang berguna untuk mengukur besarnya aset perusahaan yang dibiayai dengan utang. Menurut Mardiyanto (2009:54), rasio ini mengukur dua hal, yaitu proporsi utang perusahaan yang dipergunakan untuk mendanai investasi dan kemampuan perusahaan untuk membayar utang jangka panjangnya.

Salah satu rasio yang dapat digunakan untuk mengukur leverage adalah rasio utang (debt ratio), yaitu rasio yang oleh Kasmir (2014:156) didefinisikan sebagai rasio yang mengukur perbandingan antara total utang dan total aset untuk menilai besarnya aset perusahaan yang didanai oleh utang atau dengan kata lain menilai besarnya pengaruh utang terhadap pengelolaan aset perusahaan.

\section{Aktivitas}

Hery (2016:178) mendefinisikan rasio aktivitas sebagai rasio yang berguna untuk mengukur efektivitas perusahaan dalam mengelola asetnya serta mengukur efisiensi perusahaan dalam mengelola sumber daya yang tersedia. Menurut Mardiyanto (2009:54), rasio aktivitas adalah ukuran kemampuan aset dari suatu perusahaan dalam menghasilkan pendapatan dan/atau penjualan. Sementara itu, Martono dan Harjito (2010:56) mengartikan rasio aktivitas sebagai ukuran efektivitas manajemen perusahaan dalam mengelola asetnya.

Salah satu rasio yang dapat digunakan untuk mengukur aktivitas perusahaan adalah rasio perputaran total aset (total assets turnover ratio), yaitu rasio yang oleh Kasmir (2014) didefinisikan sebagai rasio yang mengukur perputaran semua aset perusahaan dan besarnya penjualan yang dihasilkan dari setiap aset tersebut. Kasmir (2014:186) merumuskan total asset turnover sebagai perbandingan antara penjualan dan total aset suatu perusahaan.

\section{Profitabilitas}

Mardiyanto (2009:54) mendefinisikan rasio profitabilitas sebagai ukuran kemampuan perusahaan dalam menghasilkan laba. Menurut Kasmir (2014:114), rasio profitabilitas merupakan rasio yang menilai kemampuan perusahaan dalam menghasilkan laba di suatu periode tertentu dengan menggunakan seluruh aset dan modal yang tersedia.

Salah satu rasio yang dapat digunakan untuk mengukur profitabilitas perusahaan adalah rasio pengembalian atas total aset (return on assets ratio), yaitu rasio yang oleh Fahmi (2015:137) didefinisikan sebagai rasio yang menunjukkan sejauh mana investasi 
dapat menghasilkan pengembalian berupa laba yang sesuai ekspektasi. Fahmi (2015:137) merumuskan return on asset sebagai perbandingan antara laba bersih dan total aset suatu perusahaan.

\section{Keterkaitan antara Likuiditas dan Financial Distress}

Hasil penelitian yang dilakukan oleh Widhiari dan Merkusiwati (2015) serta Hidayat dan Meiranto (2014) menunjukkan bahwa likuiditas yang diproksikan dengan current ratio terbukti memiliki pengaruh yang negatif dan signifikan terhadap financial distress. Hal tersebut mencerminkan bahwa semakin tinggi likuiditas suatu perusahaan, maka semakin tinggi pula kemampuan perusahaan tersebut dalam memenuhi kewajiban jangka pendeknya, sehingga semakin rendah kemungkinan terjadinya financial distress pada perusahaan yang dimaksud. Sejalan dengan hal tersebut, Wiagustini (2010:76) mengemukakan bahwa perusahaan yang berada dalam kondisi yang tidak sehat cenderung berada dalam posisi yang tidak likuid, sehingga perusahaan yang berada dalam kondisi yang sehat cenderung berada dalam posisi yang likuid.

$\mathrm{H}_{1}$ : Likuiditas (CR) berpengaruh negatif dan signifikan terhadap financial distress

\section{Keterkaitan antara Leverage dan Financial Distress}

Hasil penelitian yang dilakukan oleh Yustika, dkk. (2015) serta Lisiantara dan Febrina (2018) menemukan bahwa leverage yang diproksikan dengan debt ratio terbukti memiliki pengaruh yang positif dan signifikan terhadap financial distress. Hal tersebut menunjukkan bahwa semakin tinggi leverage suatu perusahaan, maka semakin tinggi pula proporsi penggunaan utang dalam pembiayaan asetnya, sehingga semakin tinggi pula kemungkinan terjadinya financial distress pada perusahaan tersebut.

Perusahaan yang memiliki debt ratio yang besar akan memiliki risiko keuangan yang besar pula dengan probabilitas default yang cukup tinggi akibat ketergantungan yang tinggi terhadap utang sebagai sumber pendanaan. Menurut Hery (2016:166), debt ratio yang membesar dapat menyulitkan kondisi keuangan suatu perusahan karena aset-aset yang dimiliki oleh perusahaan tersebut cenderung dipergunakan untuk membayar utangutangnya. Sejalan dengan hal tersebut, Brealey, et al. (2008) mengemukakan bahwa perusahaan dengan dana pinjaman dalam jumlah besar yang tidak mampu membayar utangnya sendiri cenderung akan mengalami kebangkrutan.

$\mathrm{H}_{2}$ : Leverage (DR) berpengaruh positif dan signifikan terhadap financial distress 


\section{Keterkaitan antara Aktivitas dan Financial Distress}

Menurut Mardiyanto (2009:58), tingginya nilai rasio aktivitas yang diproksikan oleh total asset turnover ratio menunjukkan tingginya efektivitas perusahaan dalam menggunakan asetnya untuk menghasilkan pendapatan dalam bentuk penjualan. Dalam kaitannya dengan financial distress, tingginya efektivitas perusahaan dalam menggunakan aset akan menyebabkan rendahnya kemungkinan terjadinya financial distress pada perusahaan yang bersangkutan karena perusahaan tersebut mampu menghasilkan penjualan yang lebih besar daripada aset yang diinvestasikannya. Sebaliknya, nilai total asset turnover ratio yang rendah menunjukkan bahwa perusahaan tidak mampu menghasilkan nilai penjualan yang sebanding dengan aset yang diinvestasikannya, sehingga memicu kemungkinan terjadinya financial distress (Hery, 2016:186). Hasil penelitian yang dilakukan oleh Noviandri (2014) serta Widhiari dan Merkusiwati (2015) juga menunjukkan bahwa aktivitas perusahaan yang diproksikan dengan total asset turnover ratio terbukti memiliki pengaruh yang negatif dan signifikan terhadap financial distress.

$\mathrm{H}_{3}$ : Aktivitas (TATO) berpengaruh negatif dan signifikan terhadap financial distress

\section{Keterkaitan antara Profitabilitas dan Financial Distress}

Yustika, dkk. (2015) serta Nukmaningtyas dan Worokinasih (2018) menemukan bahwa profitabilitas yang diproksikan dengan return on asset terbukti memiliki pengaruh yang negatif dan signifikan terhadap financial distress. Hal tersebut menunjukkan bahwa semakin tinggi profitabilitas suatu perusahaan, maka semakin tinggi pula kemampuannya dalam menghasilkan laba, sehingga semakin rendah kemungkinan terjadinya financial distress pada perusahaan tersebut karena laba yang dihasilkannya dapat dipergunakan untuk menutupi berbagai biaya dan kewajiban yang dibebankan kepadanya, sehingga perusahaan tersebut dapat terhindar dari risiko default. Sebaliknya, semakin rendah profitabilitas suatu perusahaan, maka semakin rendah pula kemampuannya dalam menghasilkan laba, sehingga semakin tinggi kemungkinan terjadinya financial distress pada perusahaan tersebut karena laba yang dihasilkannya belum tentu dapat menutupi berbagai biaya dan kewajiban yang dibebankan kepadanya, sehingga perusahaan tersebut dapat terancam oleh adanya risiko default.

$\mathrm{H}_{4}$ : Profitabilitas (ROA) berpengaruh negatif dan signifikan terhadap financial distress 


\section{Kerangka Analisis}

Kerangka analisis penelitian ini digambarkan sebagai berikut.

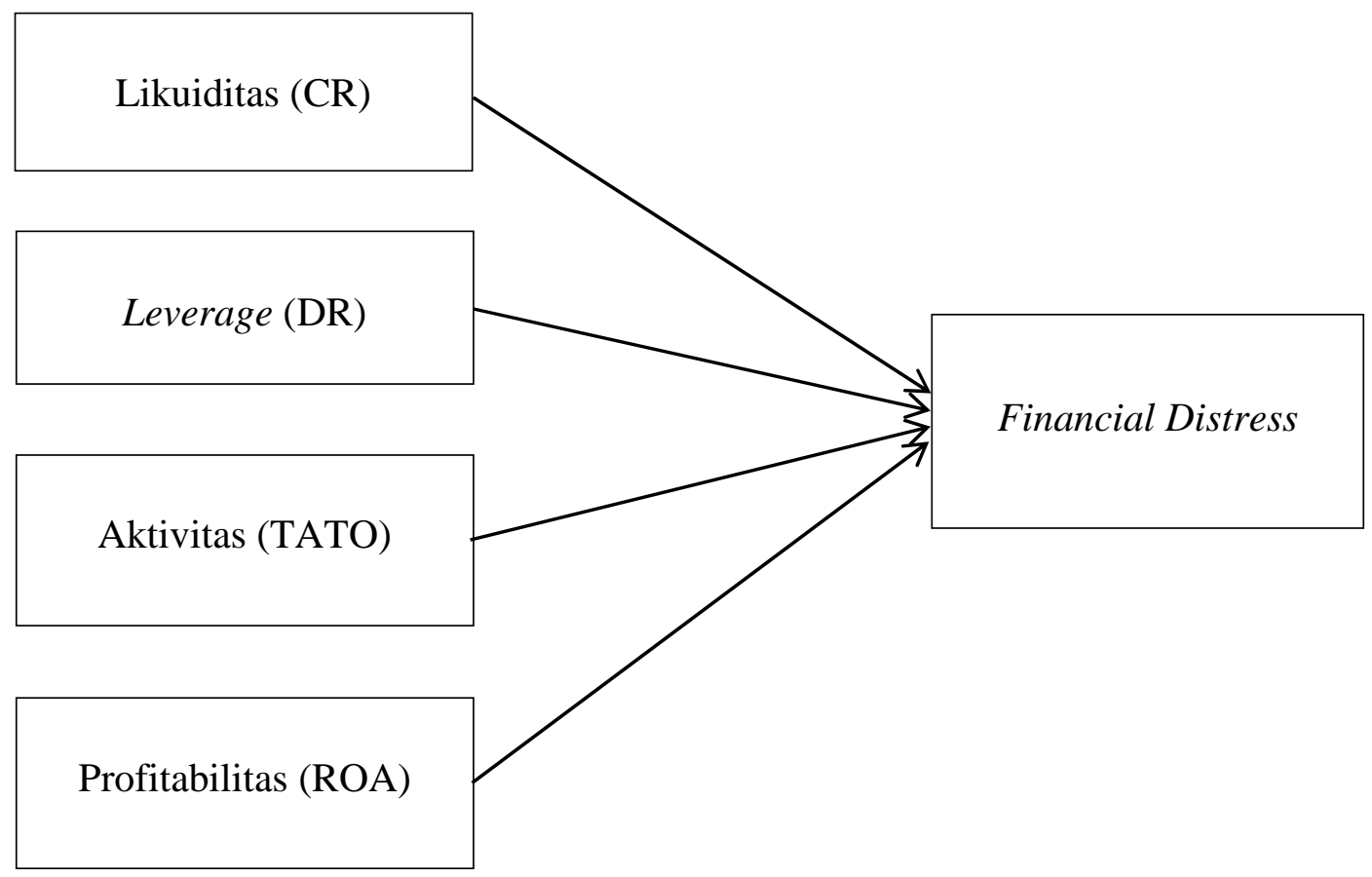

Gambar 1. Kerangka Analisis

\section{METODOLOGI PENELITIAN}

\section{Sumber dan Jenis Data}

Data penelitian merupakan data sekunder berjenis panel yang berasal dari laporan keuangan perusahaan yang bersangkutan selama periode penelitian.

\section{Populasi dan Sampel}

Populasi penelitian ini adalah perusahaan di sektor infrastruktur, utilitas dan transportasi yang terdaftar di Bursa Efek Indonesia pada periode 2011-2015. Pemilihan sampel dilakukan dengan menggunakan metode purposive sampling. Kriteria yang digunakan yaitu: (1) perusahaan telah terdaftar di BEI selama periode 2011-2015; dan (2) perusahaan memiliki laporan keuangan yang secara lengkap dipublikasikan selama periode 2011-2015.

Sampel penelitian kemudian diklasifikasikan menjadi dua kelompok, yaitu: (1) kelompok perusahaan yang diindikasikan mengalami financial distress karena memiliki EPS negatif selama minimal dua tahun berturut-turut yang dikategorikan mengalami financial distress; dan (2) perusahaan yang tidak diindikasikan mengalami financial distress karena memiliki EPS positif selama minimal dua tahun berturut-turut. 
Berdasarkan kriteria tersebut, diperoleh 32 perusahaan sebagai sampel penelitian. Dari jumlah tersebut, 14 perusahaan terindikasi mengalami financial distress, sedangkan 18 perusahaan lainnya tidak terindikasi mengalami financial distress. Dengan periode penelitian yang mencakup lima tahun, yakni sejak tahun 2011 hingga tahun 2015, maka total pengamatan dalam penelitian ini terdiri dari 160 pengamatan.

\section{Definisi Operasional dan Pengukuran Variabel}

\section{Financial Distress}

Dalam penelitian ini, financial distress diartikan sebagai penurunan kondisi keuangan perusahaan yang diindikasikan oleh nilai EPS yang negatif. Penggunaan EPS negatif sebagai indikator financial distress mengacu pada penelitian terdahulu yang dilakukan oleh Widhiari dan Merkusiwati (2015) dan Sastriana dan Fuad (2013).

Dalam penelitian ini, financial distress sebagai variabel terikat diukur dengan menggunakan variabel dummy, sehingga perusahaan yang diindikasikan mengalami financial distress diberi skor 1, sedangkan perusahaan yang diindikasikan tidak mengalami financial distress diberi skor 0.

\section{Likuiditas}

Likuiditas diartikan sebagai kemampuan perusahaan untuk memenuhi kewajibannya pada saat jatuh tempo. Dalam penelitian ini, likuiditas diproksikan dengan current ratio, yakni perbandingan antara aktiva lancar dan utang lancar.

$$
\text { Rasio Lancar (Current Ratio) }=\frac{\text { Aktiva Lancar (Current Assets) }}{\text { Utang Lancar (Current Liabilities) }}
$$

(Sumber: Weygandt et al., 2013:696)

\section{Leverage}

Leverage merupakan ukuran banyaknya aset perusahaan yang didanai oleh utang. Dalam penelitian ini, leverage diproksikan dengan debt ratio, yakni perbandingan antara total utang dan total aset.

$$
\text { Rasio Utang (Debt Ratio) }=\frac{\text { Total Utang (Total Debt) }}{\text { Total Aset (Total Assets) }}
$$

(Sumber: Brigham dan Houston, 2010:143) 


\section{Aktivitas}

Rasio aktivitas diartikan sebagai ukuran kemampuan pengelolaan aset perusahaan. Dalam penelitian ini, rasio aktivitas diproksikan dengan total assets turnover, yakni perbandingan antara penjualan dan total aset.

$$
\text { Rasio Perputaran Total Aset (Total Assets Timover Ratio) }=\frac{\text { Penjualan (Soles) }}{\text { Total Aset (Total Assets) }}
$$

(Sumber: Kasmir, 2014:186)

\section{Profitabilitas}

Profitabilitas diartikan sebagai ukuran kemampuan perusahaan untuk menghasilkan laba. Dalam penelitian ini, profitabilitas diproksikan dengan return on assets, yakni perbandingan antara laba bersih dan total aset.

$$
\text { Rasio Pengembalian atas Total Aset (Retum OnAssets Ratio) }=\frac{\text { Laba Bersih (Eamings After Tow EAT) }}{\text { Total Aset (TotalAssets) }}
$$

(Sumber: Fahmi, 2015:137)

\section{Metode Analisis}

Metode analisis yang digunakan adalah metode analisis inferensial dengan menggunakan regresi logistik.

\section{HASIL DAN PEMBAHASAN}

\section{Hasil Uji Kelayakan dan Keseluruhan Model}

Berdasarkan hasil uji kelayakan model dengan menggunakan uji Hosmer and Lemeshow, diperoleh nilai signifikansi sebesar 0,886 yang lebih besar daripada 0,05, sehingga model terbukti dapat diterima karena sesuai dengan nilai observasinya. Sementara itu, hasil uji keseluruhan model menunjukkan adanya penurunan nilai -2 Log Likelihood, yaitu dari sebesar 219,301 menjadi sebesar 120,759, sehingga menunjukkan model regresi yang lebih baik dan fit dengan data yang diambil.

\section{Hasil Uji Koefisien Determinasi}

Nilai Negelkerke's $R$ square sebesar 0,616 menunjukkan bahwa likuiditas, leverage, aktivitas, dan profitabilitas memberikan konstribusi sebesar 61,6\% dalam 
menjelaskan financial distress, sedangkan $38,4 \%$ sisanya dijelaskan oleh variabel lain yang tidak dimasukkan ke dalam model penelitian ini.

\section{Hasil Uji Regresi Logistik}

Hasil uji regresi logistik disajikan dalam tabel berikut.

Tabel 2. Hasil Uji Regresi Logistik

\begin{tabular}{|c|c|c|c|c|c|}
\hline Variabel & B & S.E. & Wald & Sig. & $\operatorname{Exp(B)}$ \\
\hline LIK & $-0,799$ & 0,341 & 5,478 & 0,019 & 0,450 \\
\hline LEV & 1,558 & 0,422 & 13,661 & 0,000 & 4,751 \\
\hline AKT & $-2,061$ & 0,887 & 5,402 & 0,020 & 0,127 \\
\hline PRO & $-18,031$ & 4,453 & 16,399 & 0,000 & 0,000 \\
\hline Constant & 0,623 & 0,629 & 0,981 & 0,322 & 1,864 \\
\hline
\end{tabular}

(Sumber: Data diolah, 2018)

Berdasarkan tabel di atas, diperoleh persamaan sebagai berikut.

$$
\operatorname{Ln} \frac{F D}{1-F D}=0,623-0,799 \text { LIK + 1,558 LEV - 2,061 AKT - 18,031 PRO }
$$

Keterangan:

$$
\begin{array}{ll}
\operatorname{Ln} \frac{F D}{1-F D} & =\text { Nilai satu untuk perusahaan financial distress dan nilai nol untuk } \\
& \text { perusahaan non-financial distress } \\
\text { LIK } & \text { Likuiditas } \\
\text { LEV } & \text { Leverage } \\
\text { AKT } & =\text { Aktivitas } \\
\text { PRO } & =\text { Profitabilitas }
\end{array}
$$

\section{Hasil Uji Hipotesis}

Berdasarkan tabel 2, diperoleh hasil pengujian hipotesis sebagai berikut.

1. Likuiditas (CR) berpengaruh negatif dan signifikan terhadap financial distress pada perusahaan terbuka di sektor infrastruktur, utilitas, dan transportasi.

2. Leverage (DR) berpengaruh positif dan signifikan terhadap financial distress pada perusahaan terbuka di sektor infrastruktur, utilitas, dan transportasi.

3. Aktivitas (TATO) berpengaruh negatif dan signifikan terhadap financial distress pada perusahaan terbuka di sektor infrastruktur, utilitas, dan transportasi.

4. Profitabilitas (ROA) berpengaruh negatif dan signifikan terhadap financial distress pada perusahaan terbuka di sektor infrastruktur, utilitas, dan transportasi. 


\section{Pembahasan}

\section{Pengaruh Likuiditas (CR) terhadap Financial Distress}

Hasil penelitian ini membuktikan bahwa likuiditas (CR) berpengaruh negatif dan signifikan terhadap financial distress, sehingga semakin tinggi likuiditas suatu perusahaan, maka semakin rendah kemungkinan terjadinya financial distress pada perusahaan tersebut karena semakin tingginya kemampuan perusahaan yang dimaksud dalam memenuhi kewajiban jangka pendeknya. Sebaliknya, semakin rendah likuiditas suatu perusahaan, maka semakin tinggi kemungkinan terjadinya financial distress pada perusahaan tersebut karena semakin rendahnya kemampuan perusahaan yang dimaksud dalam memenuhi kewajiban jangka pendeknya. Hal tersebut sejalan dengan hasil penelitian yang dilakukan oleh Widhiari dan Merkusiwati (2015) serta Hidayat dan Meiranto (2014) yang menunjukkan bahwa likuiditas (CR) berpengaruh negatif dan signifikan terhadap financial distress. Wiagustini (2010:76) juga mengemukakan bahwa perusahaan yang berada dalam kondisi yang tidak sehat cenderung berada dalam posisi yang tidak likuid, sehingga perusahaan yang berada dalam kondisi yang sehat cenderung berada dalam posisi yang likuid.

\section{Pengaruh Leverage (DR) terhadap Financial Distress}

Hasil penelitian ini membuktikan bahwa leverage (DR) berpengaruh positif dan signifikan terhadap financial distress, sehingga semakin tinggi leverage suatu perusahaan, maka semakin tinggi pula kemungkinan financial distress yang dialami oleh perusahaan tersebut. Sebaliknya, semakin rendah leverage suatu perusahaan, maka semakin rendah pula kemungkinan terjadinya financial distress pada perusahaan tersebut. Hal tersebut sejalan dengan hasil penelitian yang dilakukan oleh Yustika, dkk. (2015) serta Lisiantara dan Febrina (2018) yang menunjukkan bahwa leverage yang diproksikan dengan debt ratio terbukti berpengaruh positif dan signifikan terhadap financial distress.

Pengaruh positif yang diberikan oleh leverage yang diproksikan oleh debt ratio terhadap financial distress timbul karena perusahaan yang memiliki debt ratio yang besar akan memiliki risiko keuangan yang besar pula dengan probabilitas default yang cukup tinggi akibat ketergantungan yang tinggi terhadap utang sebagai sumber pendanaan. Menurut Hery (2016:166), debt ratio yang membesar dapat menyulitkan kondisi keuangan suatu perusahan karena aset-aset yang dimiliki oleh perusahaan tersebut cenderung dipergunakan untuk membayar utang-utangnya. Sejalan dengan hal tersebut, Brealey, et al. 
(2008) mengemukakan bahwa perusahaan dengan dana pinjaman dalam jumlah besar yang tidak mampu membayar utangnya sendiri cenderung akan mengalami kebangkrutan.

\section{Pengaruh Aktivitas (TATO) terhadap Financial Distress}

Hasil penelitian ini membuktikan bahwa aktivitas (TATO) berpengaruh negatif dan signifikan terhadap financial distress, sehingga semakin besar nilai rasio aktivitas suatu perusahaan, maka semakin kecil kemungkinan terjadinya financial distress pada perusahaan tersebut. Sebaliknya, semakin kecil nilai rasio aktivitas suatu perusahaan, maka semakin besar kemungkinan terjadinya financial distress pada perusahaan tersebut. Hal tersebut sejalan dengan hasil penelitian yang dilakukan oleh Noviandri (2014) serta Widhiari dan Merkusiwati (2015) yang menunjukkan bahwa aktivitas (TATO) berpengaruh negatif dan signifikan terhadap financial distress.

Menurut Mardiyanto (2009:58), tingginya nilai rasio aktivitas yang diproksikan oleh total asset turnover ratio menunjukkan tingginya efektivitas perusahaan dalam menggunakan asetnya untuk menghasilkan pendapatan dalam bentuk penjualan. Dalam kaitannya dengan financial distress, tingginya efektivitas perusahaan dalam menggunakan aset akan menyebabkan rendahnya kemungkinan terjadinya financial distress pada perusahaan yang bersangkutan karena perusahaan tersebut mampu menghasilkan penjualan yang lebih besar daripada aset yang diinvestasikannya. Sebaliknya, nilai total asset turnover ratio yang rendah menunjukkan bahwa perusahaan tidak mampu menghasilkan nilai penjualan yang sebanding dengan aset yang diinvestasikannya, sehingga memicu kemungkinan terjadinya financial distress (Hery, 2016:186).

\section{Pengaruh Profitabilitas (ROA) terhadap Financial Distress}

Hasil penelitian ini membuktikan bahwa profitabilitas (ROA) berpengaruh negatif dan signifikan terhadap financial distress, sehingga semakin tinggi profitabilitas suatu perusahaan, maka semakin tinggi pula kemampuannya dalam menghasilkan laba, sehingga semakin rendah kemungkinan terjadinya financial distress pada perusahaan tersebut karena laba yang dihasilkannya dapat dipergunakan untuk menutupi berbagai biaya dan kewajiban yang dibebankan kepadanya, sehingga perusahaan tersebut dapat terhindar dari risiko default. Sebaliknya, semakin rendah profitabilitas suatu perusahaan, maka semakin rendah pula kemampuannya dalam menghasilkan laba, sehingga semakin tinggi kemungkinan terjadinya financial distress pada perusahaan tersebut karena laba yang dihasilkannya belum tentu dapat menutupi berbagai biaya dan kewajiban yang dibebankan 
kepadanya, sehingga perusahaan tersebut dapat terancam oleh adanya risiko default. Hal tersebut sejalan dengan hasil penelitian yang dilakukan oleh Yustika, dkk. (2015) serta Nukmaningtyas dan Worokinasih (2018) yang menunjukkan bahwa profitabilitas (ROA) berpengaruh negatif dan signifikan terhadap financial distress.

\section{KESIMPULAN DAN SARAN}

\section{Kesimpulan}

Berdasarkan hasil penelitian ini, dapat disimpulkan hal-hal sebagai berikut.

1. Likuiditas yang diproksikan dengan current ratio (CR) berpengaruh negatif dan signifikan terhadap financial distress pada perusahaan terbuka sektor infrastruktur, utilitas, dan transportasi.

2. Leverage yang diproksikan dengan debt ratio (DR) berpengaruh positif dan signifikan terhadap financial distress pada perusahaan terbuka sektor infrastruktur, utilitas, dan transportasi.

3. Aktivitas yang diproksikan dengan total assets turnover ratio (TATO) berpengaruh negatif dan signifikan terhadap financial distress pada perusahaan terbuka sektor infrastruktur, utilitas, dan transportasi.

4. Profitabilitas yang diukur dengan return on assets ratio (ROA) berpengaruh negatif dan signifikan terhadap financial distress pada perusahaan terbuka sektor infrastruktur, utilitas, dan transportasi.

\section{Saran}

Berdasarkan kesimpulan di atas, berikut ini dirumuskan beberapa saran yang dapat dipertimbangkan oleh pihak-pihak yang berkepentingan.

1. Perusahaan perlu menjaga rasio likuiditas dan aktivitasnya di tingkat yang cukup tinggi untuk menghindari terjadinya financial distress.

2. Perusahaan perlu menjaga rasio leverage-nya agar berada di tingkat yang wajar dan tidak terlalu tinggi.

3. Perusahaan perlu senantiasa meningkatkan kemampuannya dalam menghasilkan laba.

4. Dalam memutuskan perusahaan tempatnya berinvestasi, investor hendaknya mempertimbangkan perusahaan dengan likuiditas yang cukup tinggi hingga batas tertentu, leverage yang cukup rendah hingga batas tertentu, rasio aktivitas yang cukup besar dan wajar, serta profitabilitas yang tinggi dalam rangka memastikan bahwa 
perusahaan tersebut merupakan perusahaan yang terhindar dari financial distress dan berbagai gejalanya.

\section{DAFTAR PUSTAKA}

Brigham, E.F. dan J.F. Houston. 2007. Essentials of Financial Management. Cengage Learning Asia Pte Ltd. Singapore. Terjemahan A.A. Yulianto. 2010. Dasar-dasar Manajemen Keuangan. Edisi 11. Salemba Empat. Jakarta.

Bursa Efek Indonesia. 2016. Laporan Keuangan dan Tahunan. www.idx.co.id. 2 Oktober $2016(14: 00)$.

Fahmi, I. 2015. Analisis Laporan Keuangan. Alfabeta. Bandung.

Hery. 2016. Analisis Laporan Keuangan. Integrated and Comprehensive Edition. Grasindo. Jakarta.

Hidayat, M.A. dan W. Meiranto. 2014. Prediksi Financial Distress Perusahaan Manufaktur di Indonesia. Diponegoro Journal of Accounting. 3(3): 1-11

Kasmir. 2014. Analisis Laporan Keuangan. RajaGrafindo Persada. Jakarta.

Lisiantara, G.A. dan L. Febrina. 2018. Likuiditas, Leverage, Operating Capacity, Profitabilitas, Sales Growth sebagai Prediktor Financial Distress: Studi Empiris pada Perusahaan Manufaktur yang Terdaftar di Bursa Efek Indonesia Tahun 20132016. Prosiding SENDI U. 25 Juli 2018. Universitas Stikubank Semarang: 764772.

Mardiyanto, H. 2009. Inti Sari Manajemen Keuangan. Grasindo. Jakarta.

Martono dan D.A. Harjito. 2010. Manajemen Keuangan. Edisi Pertama. Ekonisia. Yogyakarta.

Noviandri, T. 2014. Peranan Analisis Rasio Keuangan dalam Memprediksi Kondisi Financial Distress Perusahaan Sektor Perdagangan. Jurnal Ilmu Manajemen. 2(4): 1655-1665.

Nukmaningtyas, F. dan S. Worokinasih. 2018. Penggunaan Rasio Profitabilitas, Likuiditas, Leverage dan Arus Kas untuk Memprediksi Financial Distres: Studi pada Perusahaan Sektor Aneka Industri yang Terdaftar di Bursa Efek Indonesia Periode 2013-2016. Jurnal Administrasi Bisnis. 61(2): 136-143.

Sastriana, D. dan Fuad. 2013. Pengaruh Corporate Governance dan Firm Size terhadap Perusahaan yang Mengalami Kesulitan Keuangan (Financial Distress). Diponegoro Journal of Accounting. 2(3): 1-10.

Sjahrial, D. 2007. Manajemen Keuangan Lanjutan. Edisi Pertama. Mitra Wacana Media. Jakarta. 
Weygandt, J.J., P.D. Kimmel dan D.E. Kieso. 2013. Financial Accounting IFRS Edition. $2^{\text {nd }}$ Edition. John Wiley \& Sons. New Jersey.

Wiagustini, N.L.P. 2010. Dasar-Dasar Manajemen Keuangan. Udaya University Press. Denpasar.

Widhiari, N.L.M.A. dan N.K.L.A. Merkusiwati. 2015. Pengaruh Rasio Likuiditas, Leverage, Operating Capacity, dan Sales Growth Terhadap Financial Distress. EJurnal Akuntansi Universitas Udayana. 11(2): 456-459.

Yustika, Y., Kirmizi dan A. Silfi. 2015. Pengaruh Likuiditas, Leverage, Profitabilitas, Operating Capacity dan Biaya Agensi Manajerial terhadap Financial Distress: Studi Empiris pada Perusahaan Manufaktur yang Terdaftar di Bursa Efek INdonesia Tahun 2011-2013. Jom FEKON. 2(2): 1-15. 